\title{
Evaluation of Pre-Cecal, Ileal Digestibility and Glycemic Response in Fistulated Horses Fed with Different Starch Sources
}

\author{
Alexandre Augustode Oliveira Gobesso ${ }^{1}$, Mariano Etchichury ${ }^{1}$, José Esler de Freitas Jr. ${ }^{1}$, \\ Francisco Palma Rennó ${ }^{1}$, Hugo Tosi ${ }^{2}$ \\ ${ }^{1}$ Department of Nutrition and Animal Production, Faculty of Veterinary Medicine, School of Veterinary \\ Medicine and Animal Science, University of São Paulo, Pirassununga, Brazil \\ ${ }^{2}$ Department of Animal Science, São Paulo State University, Jaboticabal, Brazil \\ Email: gobesso.fmvz@usp.br
}

Received 28 December 2014; accepted 10 January 2015; published 15 January 2015

Copyright (C) 2015 by authors and Scientific Research Publishing Inc.

This work is licensed under the Creative Commons Attribution International License (CC BY). http://creativecommons.org/licenses/by/4.0/

(c) (i) Open Access

\begin{abstract}
The objective of this study was to evaluate the coefficients of pre-cecal, ileal digestibility, and glycemic response in cannulated horses fed with different starch sources. Four male horses were used in a $4 \times 4$ Balanced Latin Square cannulated in the cecum, with 36 months of age and average weight of $350 \mathrm{~kg}$. The horses were fed with hay and the following sources of starch in concentrates: 1) corn (C); 2) oats (O); 3) sorghum (S); and 4) corn/oats (CO). The experiment consisted of four periods of eighteen days each, being the first twelve days of adaptation and six days to collect samples. There was no difference in cecal and ileal digestibility of starch, CP, ADF, NDF and OM among diets evaluated. However, horses fed with oats diet had higher values of pre-cecal apparent digestibility of DM in relation at the horses fed to sorghum and corn/oats diets. The values of CF digestibility were higher for equines fed with oats and sorghum diet compared to corn/oats diet. The horses fed with corn/oats diet had lower plasma glucose concentrations 30 minutes before the supply and higher insulin concentrations 210 minutes after ingestion of the foods. The digestibility of nutrients in equine diets, in pre-cecal and pre-ileal evaluation, presents significant differences, depending on the starch source provided, oat, corn or sorghum. The plasma glucose concentrations are directly correlated with the digestibility of starch.
\end{abstract}

\section{Keywords}

Horses, Pre-Cecal Digestibility, Fistula, Ileum, Glucose

How to cite this paper: Gobesso, A.A.O., Etchichury, M., de Freitas Jr., J.E., Rennó, F.P. and Tosi, H. (2015) Evaluation of Pre-Cecal, Ileal Digestibility and Glycemic Response in Fistulated Horses Fed with Different Starch Sources. Food and Nutrition Sciences, 6, 151-160. http://dx.doi.org/10.4236/fns.2015.61016 


\section{Introduction}

The knowledge about nutrition, physiology of digestion and physiological responses related to feed evaluation in horses has been the subject of many scientific papers [1]-[3]. However, the progress in research related to this subject has found barriers, especially in regard to the energy metabolism post-absorptive.

This occurs because the knowledge of the equine digestive physiology is essential for consistent nutritional practice. And so, this information is not available in the evaluation systems of feed for horses, and many countries use as an alternative, feed composition tables for ruminants.

The interest in defining the appropriate location for the best digestion for the different nutrients, has been the subject of many research papers and is generating a lot of questions [1] [4] [5], since individual variations and the interference of various factors can cause the appearance of different results in each test performed. Reference [6] mentioned that the knowledge in relation to the ability of the small intestine for digestion of protein was needed to better understanding of the supply and use of amino acids. However, studies of pre-cecal digestion in horses are recent and the collection methods in this part of the intestine are not well established, and it is of fundamental importance in determination of the nutrients partial digestibility [7].

Recent studies have demonstrated clear links between post-absorptive effects, eating behavior and feed processing techniques in exercised horses. These observations need to be examined to answer questions arising from studies that have examined, in isolation, interactions between behavioral processes, digestion and the postabsorptive state. If a concerted effort is made, there is considerable scope to develop robust strategies for appropriate feed processing systems to improve understanding of the processes of voluntary intake and nutrient use by horses [8] [9].

The importance of conducting digestion trials with the use of fistulated horses, mainly in the distal ileum, would allow obtaining data of partial digestion, pre-cecal and post-ileal of the nutrients and the respective physiological response of the nutrients digestion.

Thus the aim of this study was to evaluate the pre-cecal and ileal apparent digestibility of dry matter and nutrients and to quantify the glycemic response in animals fed with the different concentrates.

\section{Material and Methods}

\subsection{Animals and Treatments}

All experimental procedures applied in this paper follow the "Ethical Principles in Animal Experimentation" recommended by the Brazilian College of Animal Experimentation.

The experiment was carried out at the Equine Feeding and Exercise Physiology Laboratory, Department of Nutrition and Animal Production, School of Veterinary Medicine and Animal Science, São Paulo University, Pirassununga/São Paulo, Brazil.

\subsection{Animals and Diets}

Four horses males cannulated in the ileum with age of 36 months and average live weight of $350 \mathrm{~kg}$ were used in a $4 \times 4$ Balanced Latin Square. The experiment consisted of four periods of eighteen days each, being the first twelve days of food adaptation, three days for total collection of feces and three days for collection of ilealcontent [10] [11]. The equine were cannulated in the distal ileum, according to the technique described [12] with implantation of rubber cannulas "T" model. After surgery were kept in individual stalls of $3.5 \times 3.5 \mathrm{~m}$, with concrete floor and without bed during the fecal collection, provided with feeder and drinker. To avoid the stress caused by confinement were exercised daily, led by the halter, to rides on paved road.

To determine the digestibility of dry matter and nutrients, four treatments were used, composed by forage (grass hay-Cynodondactylon (1) Pers. var. Coast cross-1) and concentrate, pellet, whose variation was the starch source (Table 1).

The treatments provided were: 1) corn treatment (C): hay + concentrate based on corn; 2) oats treatment (O): hay + concentrate based on oats; 3 ) sorghum treatment (S): hay + concentrate based on sorghum and; 4) corn/oats treatment (CO): hay + concentrate based on corn/oats (50\%/50\%).

The feed was provided in two meals, with regular intervals, at 7:00 and 19:00 hours, and the total food (hay + concentrate) was divided equally between the meals, adopting the individual daily consumption of $2 \%$ body weight, $40 \%$ concentrate and $60 \%$ roughage. The concentrate was supplied in feeder separated of the roughage 
Table 1. Bromatological composition of concentrate (\% DM) and grass hay tifton 85 (cynodons) according to the experimental treatment.

\begin{tabular}{|c|c|c|c|c|c|}
\hline \multirow{2}{*}{ Ingredients } & \multicolumn{4}{|c|}{ Treatments } & \multirow{2}{*}{ Tifton 85 hay } \\
\hline & $\mathrm{C}^{\mathrm{a}}$ & $\mathrm{O}^{\mathrm{b}}$ & $\mathrm{S}^{\mathrm{c}}$ & $\mathrm{CO}^{\mathrm{d}}$ & \\
\hline \multicolumn{6}{|l|}{ Nutrients $\mathrm{g} / \mathrm{kg}$ of DM } \\
\hline Dry matter & 906.0 & 908.0 & 903.0 & 908.0 & 908.0 \\
\hline Organic matter & 832.0 & 836.0 & 806.0 & 804.0 & 855.0 \\
\hline Crude ash & 74.0 & 72.0 & 97.0 & 104.0 & 53.0 \\
\hline Ether extract & 34.0 & 40.0 & 15.0 & 32.0 & 4.0 \\
\hline Crude fiber & 211.0 & 190.0 & 173.0 & 153.0 & 36.0 \\
\hline Calcium & 8.0 & 7.0 & 6.0 & 9.0 & 1.0 \\
\hline Phosphorus & 3.0 & 7.0 & 6.0 & 7.0 & 2.0 \\
\hline Neuter detergent fiber & 262.0 & 248.0 & 289.0 & 298.0 & 868.0 \\
\hline Acid detergent fiber & 136.0 & 127.0 & 178.0 & 145.0 & 461.0 \\
\hline Starch & 467.0 & 475.0 & 473.0 & 437.0 & 63.0 \\
\hline
\end{tabular}

${ }^{\mathrm{a}}$ Corn; ${ }^{\mathrm{b}}$ Oats; ${ }^{\mathrm{c}}$ Sorghum; ${ }^{\mathrm{d}}$ Corn + oats.

and implemented a time of maximal consumption for the concentrate of 45 minutes to standardize the digestibility studies as methodology adopted by [6]. The roughage was offered at the same time in which the concentrate, according to [13].

The horses were weighed at the beginning and end of each treatment and the formulation of diets were made to meet the maintenance requirements of the equine used, according to [14].

\subsection{Samples Collect}

Individual samples of the diets and ingredients supplied, and orts were collected daily and stored during the periods of sampling, being packed in plastic bags.

The ileal content was collected from 1 hour after the first feeding, with intervals of 3 hours. At the time of collection, ileal cannula was opened and the content present in the stem of the cannula despised. Plastic bags used were positioned to collect the intestinal contents which flowed, spontaneously, approximately every 15 seconds to complete at least $100 \mathrm{ml}$. The feces were placed in plastic buckets, identified by the horse, and the total amount excreted, after homogenization, was withdrawn 10\%, packed in plastic bags and frozen for later analysis. On the second day the samples were performed one hour after the time of day before, and so successively. The samples were stored in plastic bags and frozen immediately.

After four periods of sampling, samples of ileal content of the feed provided and orts were thawed at room temperature, manually homogenized, weighed and dried in stove with forced ventilation at $65^{\circ} \mathrm{C}$ for 72 hours. Soon after was ground in hammer mill type willy, with sieve of $1 \mathrm{~mm}$.

Pre-dried samples of ileal content were grouped for determination of the pre-cecal digestibility, so to represent 24 hours of ileal flow, 12 hours of diurnal ileal flow, from 8:00 to 19:00 hours and 12 hours of nocturnal flow, from 20:00 to 7:00 hours. All samples, after being milled, were packed in glass containers with polyethylene cover and stored for later analysis.

Analyses of glucose [15] were measured using commercial Laborlab ${ }^{\circledR}$ (São Paulo, Brazil) kits for method colorimetric with an automatic biochemistry analyzer (Automatic System of Biochemistry Model-SBA-200Modern Laboratory Equipment Company, MLEC ${ }^{\circledR}$-Barueri, São Paulo, Brazil).

The analysis of dry matter (DM), organic matter (OM), crude protein (CP) was performed using the methodology described by [16]. The starch analysis was conducted using the enzymatic method described by [12]. The determination of the concentration of crude fiber (CF), acid detergent fiber (ADF) and neural detergent fiber (NDF) were performed according to methodology described by [17].

The pre-cecal digestibility was calculated using the following formula:

$$
\text { Pre-cecal digestibility }(\%)=\frac{\text { DM intake } *(\% \text { fraction })-\text { ileal DM flow } *(\% \text { fraction })}{\text { DM intake } *(\% \text { fraction })} \times 100 \text {. }
$$




\subsection{Statistical Analysis}

Data were analyzed using PROC MIXED of SAS (Version 9.1, SAS Institute, Cary, NC 2004) [18], and was previously verified the normality of residuals by SHAPIRO-WILK test and the variances were compared by $\mathrm{F}$ test, adopting a significance level of $5 \%$ for all tests. The data were analyzed using the model:

$$
Y i j k=\mu+A i+P j+T k+e i j k l
$$

where: Yijk = characteristic observed for the digestibility of nutrients for the animal $i$, in the period $j$ and in the treatment $k ; \mu$ overall mean, $A i=$ effect of animal $i(i=1$ to 4$), P j=$ effect of period $j(j=1$ to 4$), T k=$ effect of treatment $k(k=1$ to 4$)$; eijk = random residual error. Were used orthogonal contrasts: $\mathrm{C} 1=$ corn vs oats + sorghum + corn/oats; C2 = oats vs sorghum; C3 = corn vs corn/oats. SEM = stander error mean.

\section{Results}

\subsection{Digestibility}

The horses fed with oats diet had higher values of pre-cecal apparent digestibility of DM compared to animals fed with the sorghum and corn/oat treatments $(\mathrm{P}<0.05)$ (Figure $1(\mathrm{a})$ ). The values of CF digestibility were higher for animals fed with the $\mathrm{O}$ and $\mathrm{S}$ compared to $\mathrm{CO}(\mathrm{P}<0.05)$ (Figure $1(\mathrm{~b})$ ). There were no differences for the pre-cecal apparent digestibility of nutrients $\mathrm{OM}, \mathrm{CP}$, ADF and NDF among experimental diets $(\mathrm{P}>0.05)$ (Table 2).

There was greater contribution pre-cecal of OM when observing the mean coefficients of pre-cecal and postileal apparent digestibility of DM and OM for diets evaluated. By the other side, there was similarity to the prececal and post-ileal digestibility coefficients of CP among the experimental diets. The corn/oatsfood had a

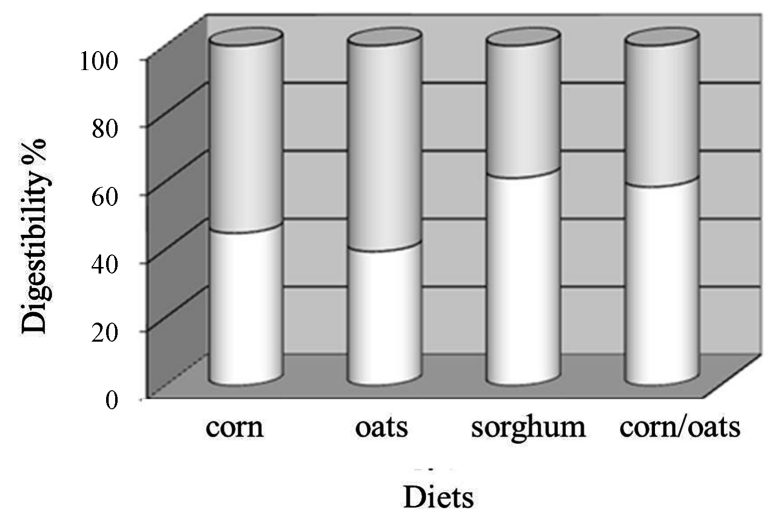

口 PCADC

口 PIADC

(a)

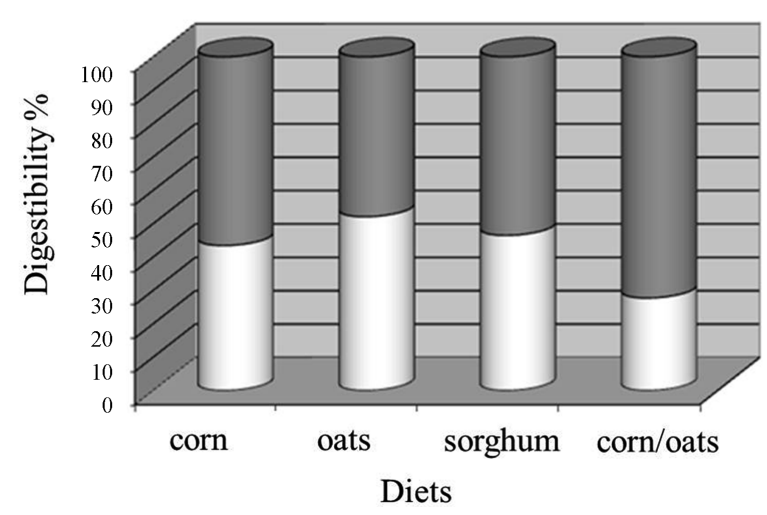

口 PCADCF

口 PIADCF

(b)

Figure 1. Comparison between the pre-cecal apparent digestibility (PCAD) and post-ileal (PIAD) of CF (\%) (a), and pre-cecal apparent digestibility of dry matter (PCADC) (b). 
Table 2. Mean values of the pre-cecal apparent digestibility of nutrients according to the treatments.

\begin{tabular}{|c|c|c|c|c|c|}
\hline \multirow{3}{*}{ Item } & \multicolumn{4}{|c|}{ Treatments } & \multirow{3}{*}{ SEM } \\
\hline & $\mathrm{C}^{\mathrm{a}}$ & $\mathrm{O}^{\mathrm{b}}$ & $\mathrm{S}^{\mathrm{c}}$ & $\mathrm{CO}^{\mathrm{d}}$ & \\
\hline & \multicolumn{4}{|c|}{ g/g of DM } & \\
\hline Dry matter & $0.174^{\mathrm{ab}}$ & $0.218^{\mathrm{a}}$ & $0.133^{\mathrm{bc}}$ & $0.086^{\mathrm{c}}$ & 1.43 \\
\hline Organic matter & 0.331 & 0.368 & 0.269 & 0.335 & 1.28 \\
\hline Crude protein & 0.346 & 0.287 & 0.428 & 0.288 & 2.54 \\
\hline Starch & 0.945 & 0.941 & 0.935 & 0.944 & 0.22 \\
\hline Crude fiber & $0.234^{\mathrm{ab}}$ & $0.275^{\mathrm{a}}$ & $0.271^{\mathrm{a}}$ & $0.144^{\mathrm{b}}$ & 0.38 \\
\hline Acid detergent fiber & 0.266 & 0.312 & 0.291 & 0.286 & 1.82 \\
\hline Neuter detergent fiber & 0.268 & 0.354 & 0.327 & 0.272 & 1.07 \\
\hline
\end{tabular}

${ }^{\mathrm{a}, \mathrm{b}, \mathrm{c}}$ Means followed by the same letter did not differ $(\mathrm{P}>0.05)$ by tukey test. ${ }^{\mathrm{a} C o r n ;}{ }^{\mathrm{b}}$ Oats; ${ }^{\mathrm{c}}$ Sorghum; ${ }^{\mathrm{d}}$ Corn + oats.

smaller pre-cecal digestion of CF compared to corn, oat and sorghum treatments. In NDF digestibility was higher for both digestive tracts in the digestion of the four diets. The digestibility of ADF was lower for the pre-cecal portion of the corn diet when compared to oat, sorghum and corn/oats diets (Table 2, Figure 2(a) and Figure 2(b)).

\subsection{Plasma Glucose and Insulin Concentration}

The concentration of glucose increased 90 minutes after ingestion of feed in the animals fed with corn, oat, sorghum and corn/oat with values of 73\%, 28,\% 52\% and 56\% respectively. Similarly, the insulin concentration was increased at 707\%, 427\%, 522\% and 883\%, for corn, oat, sorghum and corn/oat diets, respectively, after ingestion.

Animals fed with oats, corn and sorghumgroups had a higher mean plasma insulin concentration (Table 3; Figure 3(b)) 30 minutes before feeding in relation to corn/oats group $(\mathrm{P}<0.05)$. Similarly the same result was observed 210 minutes after feeding, so that the horses fed with the corn diet had higher average value than other treatments (Table 3).

Increase in plasma glucose concentrations after ingestion was observed $(\mathrm{P}<0.05)$. However, there were no differences for plasma glucose concentrations (Table 3; Figure 3(a)) among the different diets and sampling times $(\mathrm{P}>0.05)$.

\section{Discussion}

\subsection{Digestibility}

The digestibility coefficient of DM obtained in this study was smaller when compared to that obtained by [21] using the technique of horse slaughter with diets based on alfalfa hay, corn and soybean meal. This is justified due to the large amount of crude ash present in ileal content of animals evaluated ( $\mathrm{P}>0.05$; Table 2).

The average values of pre-cecal digestibility of CP (33.8\%) were lower when compared to those obtained by [2] [19] who obtained values of $39.9 \%$ for pre-cecal digestibility of CP. However, the average values of prececal digestibility of NDF (30.5\%) were higher compared to the same authors (30.5\% vs. 12.6\%) [20] [21].

Pre-cecal digestibility values of starch were higher than those observed by [22], who reported for starch digestibility of oats and corn, $87.4 \%$ and $47.3 \%$, respectively. In reference [8] also evaluated the digestion of starch at different levels of inclusion of corn grain (20\%, 40\%, 60\% and $80 \%)$ using as source of forage alfalfa hay. These authors observed differences in pre-cecal starch digestibility of $63.4 \%$; 59.6\%; 54.3\% and $65.8 \%$ for the inclusion of grain respectively. Reference [22] evaluated a series of studies on the effects of processing of oat grains and milled sorghum or micronized (heat-treated by microwave) on the partial digestion of starch in the equine distal ileum fistulated. The apparent pre-cecal digestibility coefficients of the milled oats, micronized and milled sorghum and micronized, were respectively, 55.9\%; 51.9\%; 53.0\% and 53.6\% for DM and 48.0\%; $62.3 \%$; $36.0 \%$ and $56.3 \%$ for starch. 


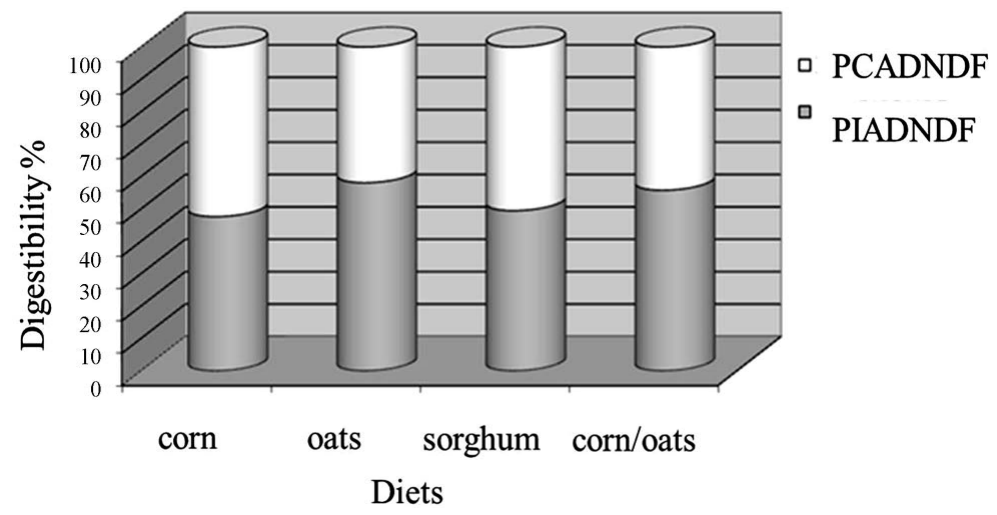

(a)

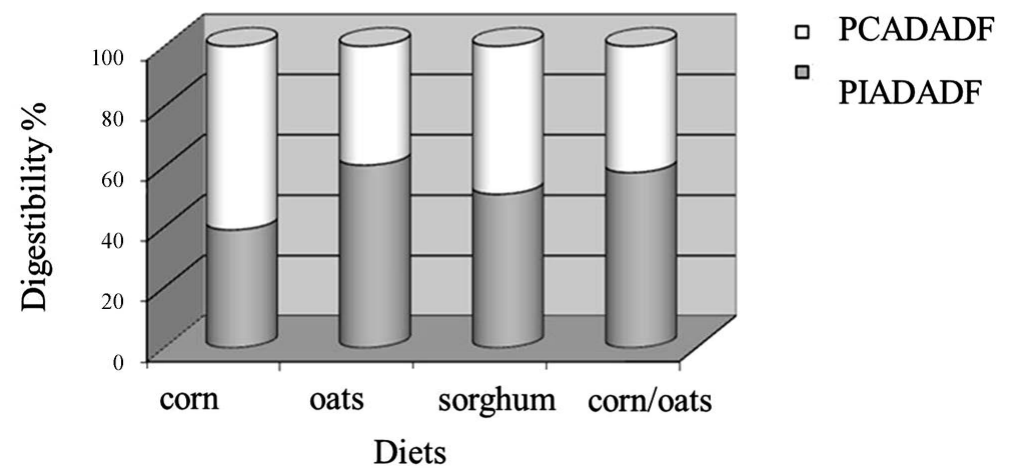

(b)

Figure 2. Comparison between the pre-cecal apparent digestibility (PCAD) and post-ileal (PIAD) of NDF (\%) (a), and pre-cecal apparent digestibility (PCAD) and post-ileal (PIAD) of ADF (\%) (b).

Table 3. Mean plasma glucose and insulin concentrations before and after the feed supply in the morning according to the treatments.

\begin{tabular}{|c|c|c|c|c|c|c|}
\hline \multirow{2}{*}{ Times (minutes) } & \multicolumn{4}{|c|}{ Treatments } & \multirow{2}{*}{ Mean } & \multirow{2}{*}{ SEM } \\
\hline & $C^{a}$ & $\mathrm{O}^{\mathrm{b}}$ & $\mathrm{S}^{\mathrm{c}}$ & $\mathrm{CO}^{\mathrm{d}}$ & & \\
\hline \multicolumn{7}{|c|}{ Glucose (mg/dl) } \\
\hline-30 & $86.93^{\mathrm{a}}$ & $86.23^{\mathrm{a}}$ & $88.03^{\mathrm{a}}$ & $85.60^{\mathrm{b}}$ & 86.70 & 0.77 \\
\hline 30 & 100.20 & 85.06 & 98.93 & 98.40 & 95.65 & 2.96 \\
\hline 90 & 150.33 & 110.73 & 133.43 & 133.93 & 132.11 & 8.95 \\
\hline 150 & 161.63 & 123.23 & 145.70 & 140.57 & 142.78 & 9.81 \\
\hline 210 & 157.13 & 116.53 & 145.03 & 130.40 & 137.28 & 1.27 \\
\hline \multicolumn{7}{|c|}{ Insulin (mg/dl) } \\
\hline-30 & 6.17 & 7.00 & 7.83 & 5.40 & 6.60 & 0.38 \\
\hline 30 & 16.93 & 14.30 & 18.00 & 16.53 & 16.44 & 0.86 \\
\hline 90 & 49.73 & 36.90 & 48.73 & 53.07 & 47.11 & 3.17 \\
\hline 150 & 85.93 & 56.97 & 74.47 & 76.80 & 73.54 & 6.96 \\
\hline 210 & $126.03^{\mathrm{a}}$ & $84.20^{\mathrm{a}}$ & $73.03^{\mathrm{b}}$ & $75.23^{\mathrm{b}}$ & 89.62 & 8.26 \\
\hline
\end{tabular}

${ }^{\mathrm{a}}$ Corn; ${ }^{\mathrm{b}}$ Oats; ${ }^{\mathrm{c}}$ Sorghum; ${ }^{\mathrm{d}}$ Corn + oats. 


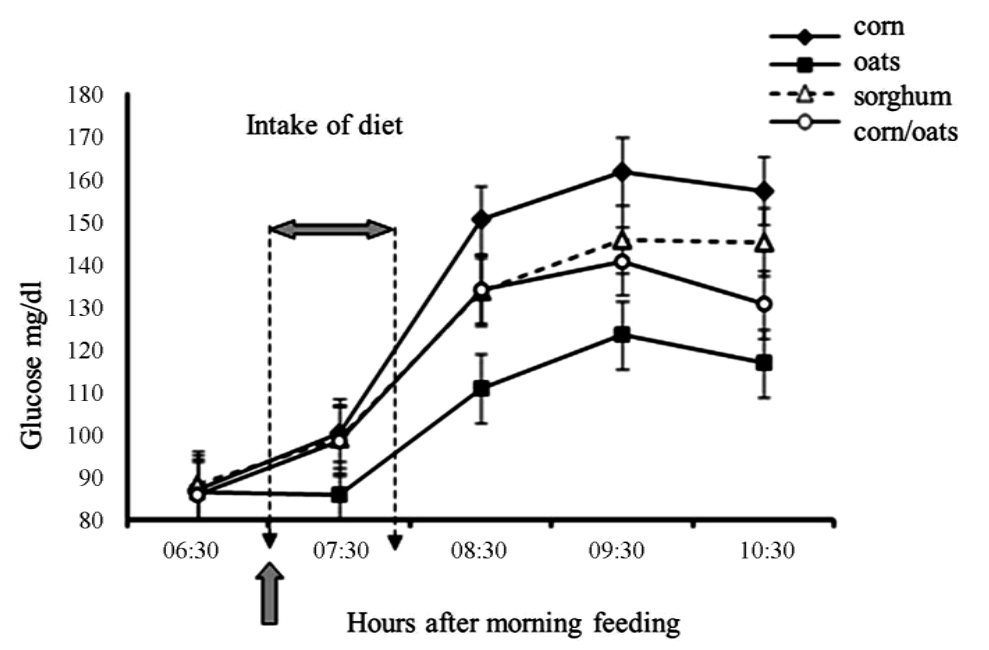

(a)

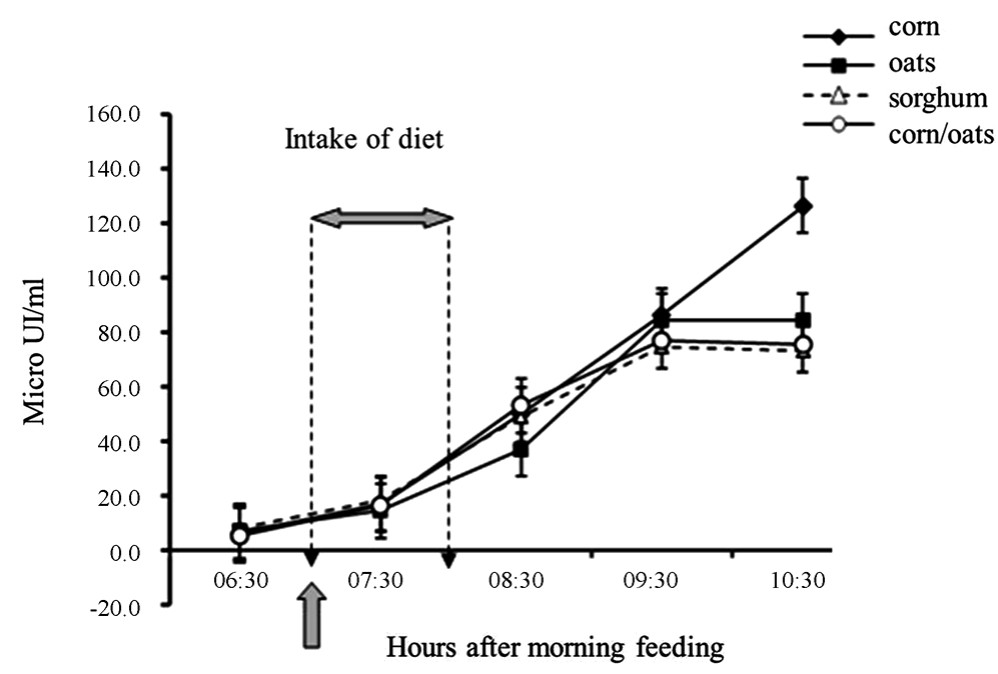

(b)

Figure 3. Plasma glucose concentrations (a) and insulin (b) to the diets.

The pre-cecal starch digestibility observed in this experiment, for corn, oats, sorghum and corn/oats diets were 94.5; 94.1; 93.5 and 94.4, respectively. These values were higher than those obtained by [12] [22] but the amount of starch in the diets used in this experiment (mean of 22.5\% of DM intake) can justify such results. According to [23] the reduction in starch digestibility in the small intestine can occur due to ingestion of large quantities of this nutrient. To feeding of horses the estimated maximum for the digestive capacity of starch in the small intestine is 3.5 to $4 \mathrm{~g}$ of starch/kg of body weight (BW) per meal. However depending of the type of starch, the overcoming the digestive capacity of the small intestinecan occur with $2 \mathrm{~g}$ of starch $/ \mathrm{kg}$ of BW in the meal [17]. In this experiment the amount of ingested starch per kg of body weight was $4 \mathrm{~g} / \mathrm{kg}$ of DM.

The possibility having occurred a reflux of cecal content due to the position of implantation of the ileal cannula, once this point is located below of the ileo-cecal-colic valve and this has little control of reflux, could justify the results of starch digestibility higher than those obtained in tests with similar objectives, using the sacrifice of animals for collection of intestinal contents, or even as [24] which used a sampling methodology with drainage of all ileal content every hour.

\subsection{Plasma Glucose and Insulin Concentration}

The plasma glucose concentration after feed ingestion can be influenced by several factors such as particle size, the degree of thermal processing, the composition at protein, fat and fiber of the feed, biochemical structure and 
process of carbohydrate absorption, the content and time interval from the previous meal [25] [26]. Reference [27] concluded there was also a significant effect of time following feeding on insulin concentrations depending on number of times feeding provided per day.

The higher plasma glucose concentrations after supply of the diets (Figure 1 and Table 3) indicate that the results are similar to those obtained by [28] who observed that the plasma glucose concentration is increased, usually one hour after feeding and tend to be low in the end of the nocturnal period. Reference [28] observed in horses, that the plasma glucose concentration, 1 hour after feeding increased $70 \%$ and the insulin, 2 hours after feeding, increased eight times. Reference [23] stated that the amount of feed and the time after ingestion are important for evaluation of plasma values of insulin. The peak plasma insulin may even triple with the increase of starch in the diet when compared with the previous values of feed intake and time of the peak is inversely proportional to amount of starch ingested. Reference [29] concluded that pelleting may increase the digestibility of starch in the small intestine, because pelleted feed produces a large increase in the concentration of glucose and insulin, compared to less processed feeds [4] [23].

The peaks plasma insulin and glucose occurred, respectively, 2.5 and 3 hours after feeding (Figure 1). In studied [18] observed similar results and concluded that the carbohydrate intake provides, glucose and insulin levels, in horses, quantitatively similar to humans. However, the absorption peak in horses, 2.5 to 3 hours after feeding, occurs later than in humans. Reference [14] emphasize that the plasma glucose peak occurs 2 to 3 hours after feed intake in the morning, and the levels increase also, immediately before ingestion. Already the insulin had his peak between 3 to 4 hours after feeding and likewise, increases at the time of diet intake.

It is important to emphasize that the instability of concentrate pellets, as previously mentioned, may have influenced the process of chewing and salivation, and so, the values of plasma glucose and insulin may have been influenced. According to [30] horses fed with milled concentrate showed plasma glucose peak at 150 minutes after intake, while animals fed with concentrate pellets, showed this peak after 180 minutes. These results suggest that more glucose is absorbed from the pelleted diet.

\section{Conclusion}

The digestibility of nutrients between the pre-cecal and pre-ileal has significant differences in equine species, depending on processing type or feed management more than starch source. The amount of dry matter digested depends on the starch source used.

\section{Implications}

More experiments are needed to investigate the vaulting complex equine digestion. They will have problems to approve ethical aspects about the invasive surgery to collect ileal contents. New forms to this collection needed to be developed.

\section{References}

[1] De Fombelle, A., Varloud, M., Goachet, A.G., Jacotot, E., Philippeau, C., Drogoul, C. and Julliand, V. (2003) Characterisation of the Microbial and Biochemical Profile of the Different Segments of the Digestive Tract in Horses Fed Two Distinct Diets. Journal Animal Science, 77, 293-304.

[2] Farley, E.B., Potter, G.D. and Gibbs, P.G. (1995) Digestion of Soybean Meal Protein in the Equine Small and Large Intestine at Various Levels of Intake. Journal of Equine Veterinary Science, 15, 391-397. http://dx.doi.org/10.1016/S0737-0806(07)80483-7

[3] Ralston, S.L. and Baile, C.A. (1982) Plasma Glucose and Insulin Concentrations and Feeding Behavior in Ponies. Journal of Animal Science, 54, 1132-1137.

[4] Drogoul, C., Tisserand, J.L. and Poncet, C. (2000) Feeding Ground and Pelleted Hay Rather than Chopped Hay to Ponies. 2. Consequences on Fibre Degradation in the Cecum and the Colon. Animal Feed Science and Technology, 87, 131-145. http://dx.doi.org/10.1016/S0377-8401(00)00188-7

[5] Gobesso, A.A.O. and Etchichury, M. (2009) Digestibilidade pré-cecal diurna e noturna em equinos fistulados alimentados com diferentes concentrados. Revista Brasileira de Saúde e Produção Animal, 10, 15-25.

[6] Gibbs, P.G., Potter, G.D. and Schelling, G.T. (1996) The Significance of Small vs. Large Intestinal Digestion of Cereal Grain and Oilseed Protein in the Equine. Journal of Equine Veterinary Science, Wildomar, 16, 60-65. 
http://dx.doi.org/10.1016/S0737-0806(96)80157-2

[7] Almeida, F.Q., Valadares Filho, S.C. and Silva, J.F.C. (1997) Digestão pré-cecal em eqüinos: 1-Protocolos de coleta ileal e estimativa do fluxo ileal de digesta. In: Reunião $D a S b z$, Juiz De Fora. Anais.

[8] Hill, J. (2007) Impacts of Nutritional Technology on Feeds Offered to Horses: A Review of Effects of Processing on Voluntary Intake, Digesta Characteristics and Feed Utilisation. Animal Feed Science and Technology, 138, 92-117. http://dx.doi.org/10.1016/j.anifeedsci.2007.06.018

[9] Resende, A.S.C., Gonçalves, L.C. and Carvalho, M.A.G. (1998) Digestibilidade aparente em equídeos submetidos a três condutas de arraçoamento. II-Frações fibrosas. Arquivo Brasileiro de Medicina Veterinária e Zootecnia, 50, 429434.

[10] Araújo, K.V., Lima, J.A.F. and Fialho, E.T. (2000) Comparação dos indicadores internos com o método de coleta total para determinar a digestibilidade dos nutrientes de dietas mistas em eqüinos. Ciência e Agrotecnologia, 24, 1041-1048.

[11] Sales, J. and Homolka, P. (2010) A Meta-Analysis of the Effects of Supplemental Dietary Fat on Protein and Fibre Digestibility in the Horse. Livestock Science, 136, 55-63.

[12] Leão, M.I., Almeida, A.A.M. and Carvalho, A.V. (1994) Técnica de fistulação no íleo terminal de eqüinos. In: Reunião Anual da Sociedade Brasileira de Zootecnia, SBZ, Maringá, 31.

[13] Potter, G.D., Arnold, F.F. and Householder, D.D. (1992) Digestion of Starch in the Small or Large Intestine of the Equine. European Conference on Horse Nutrition, No. 1.

[14] Stull, C.L. and Rodiek, A.V. (1988) Responses of Blood Glucose, Insulin and Cortisol Concentrations to Common Equine Diets. American Institute of Nutrition, 206-213.

[15] Macrae, J.C. and Armstrong, D.G. (1968) Enzyme Method for Determination of $\alpha$-Linked Glucose Polymers in Biological Materials. Journal of the Science of Food and Agriculture, 19, 578-581. http://dx.doi.org/10.1002/jsfa.2740191006

[16] Association of Official Analytical Chemists (AOAC) (1990) Official Methods of Analysis of the Association of Official Analytical Chemists. 15th Edition, Association of Official Analytical Chemists, Washington DC.

[17] Van Soest, P.J., Robertson, J.B. and Lewis, B.A. (1991) Methods for Dietary Fiber, Neutral Detergent Fiber, and NonStarch Polysaccharides in Relation to Animal Nutrition. Journal of Dairy Science, 74, 3583-3597. http://dx.doi.org/10.3168/jds.S0022-0302(91)78551-2

[18] SAS (2004) SAS/STAT User’s Guide, Version 9.1. 3rd Edition, SAS Institute Inc., Cary.

[19] Julliand, V., De Fombelle, A. and Varloud, M. (2006) Starch Digestion in Horses: The Impact of Feed Processing. Livestock Science, 100, 44-52. http://dx.doi.org/10.1016/j.livprodsci.2005.11.001

[20] Jose-Cunilleras, E., Taylor, L.E. and Hinchcliff, K.W. (2004) Glycemic Index of Cracked Corn, Oat Grouts and Rolled Barley in Horses. Journal of Animal Science, 82, 2623-2629.

[21] Hintz, H.F., Argenzio, R.A. and Schryver, H.F. (1971) Digestion Coefficients, Blood Glucose Levels and Molar Percentage of Volatile Acids in Intestinal Fluid of Ponies Fed Varying Forage-Grain Rations. Journal of Animal Science, Champaign, 33, 992-995.

[22] Guezennec, C. (1995) Oxidation Rates, Complex Carbohydrates and Exercise. Sports Medicine, 19, 365-372. http://dx.doi.org/10.2165/00007256-199519060-00001

[23] Healy, H.P., Siciliano, P.D. and Lawrence, L.M. (1995) Effect of Concentrate Form on Blood and Gastric Fluid Variables in Ponies. Journal of Equine Veterinary Science, 15, 423-428.

[24] Pratt-Philips, S., Kutzner-Mulligan, J., Marvin, R., Brow, H., Sykes, C. and Frederico, J. (2014) The Effect of Feeding Two or Three Meals per Day of either Low or High Non-Structural Carbohydrate Concentration on Postprandial Glucose and Insulin Concentration in Horses. Journal of Equine Veterinary Science, 34, 1251-1256. http://dx.doi.org/10.1016/j.jevs.2014.08.004

[25] Meyer, H., Radicke, S., Kienzle, E., Wilke, S., Kleffken, D. and Illenseer, M. (1995) Investigations on Preileal Digestion of Starch from Grain, Potato and Manioc in Horses. Journal of Veterinary Medicine Series A—Physiology Pathology Clinical Medicine, 42, 371-381. http://dx.doi.org/10.1111/j.1439-0442.1995.tb00389.x

[26] Depew, C.L., Thompson Jr., D.L., Fernandez, J.M., et al. (1994) Changes in Concentration of Hormones, Metabolites, and Amino Acids in Plasma of Adult Horses Relative to Overnight Feed Deprivation Followed by a Pellet-Hay Meal Feet at Noon. Journal of Animal Science, 72, 1530-1539.

[27] Glade, M.J., Gupa, S. and Reimers, T.J. (1984) Hormonal Responses to High and Low Planes of Nutrition in Weanling Thoroughbreds. Journal of Animal Science, 59, 658-665.

[28] National Academic (2007) Nutrient Requirements of Horses. 6th Edition, Washington DC, 341 p.

[29] Drogoul, C., Poncet, C. and Tisserand, J.L. (2000) Feeding Ground and Pelleted Hay Rather than Chopped Hay to Po- 
nies. 1. Consequences for in Vivo Digestibility and Rate of Passage of Digesta. Animal Feed Science and Technology, 87, 117-130. http://dx.doi.org/10.1016/S0377-8401(00)00187-5

[30] Hincle, D.K., Potter, G.D. and Kreider, J.L. (1983) Starch Digestion in Different Segments of the Digestive Tract of Ponies Fed Varying Levels of Corn. Equine Nutrition and Physiology Symposium, Lexington, 28-30 April 1983, 227. 
Scientific Research Publishing (SCIRP) is one of the largest Open Access journal publishers. It is currently publishing more than 200 open access, online, peer-reviewed journals covering a wide range of academic disciplines. SCIRP serves the worldwide academic communities and contributes to the progress and application of science with its publication.

Other selected journals from SCIRP are listed as below. Submit your manuscript to us via either submit@scirp.org or Online Submission Portal.
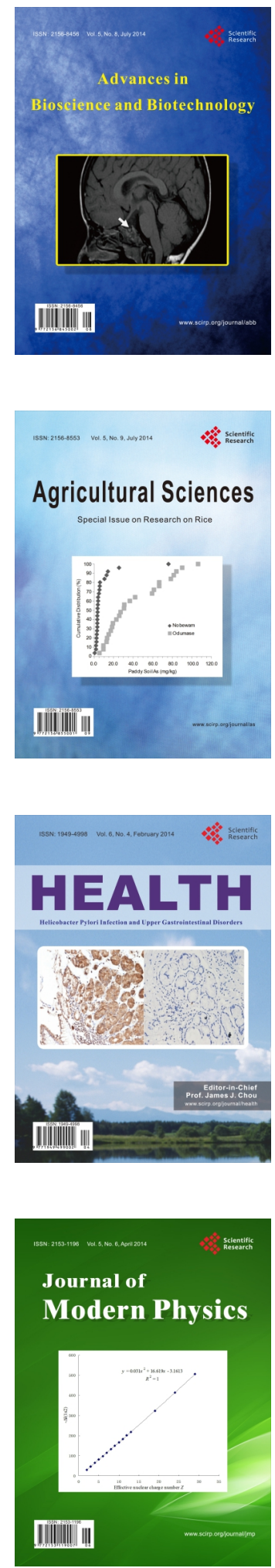
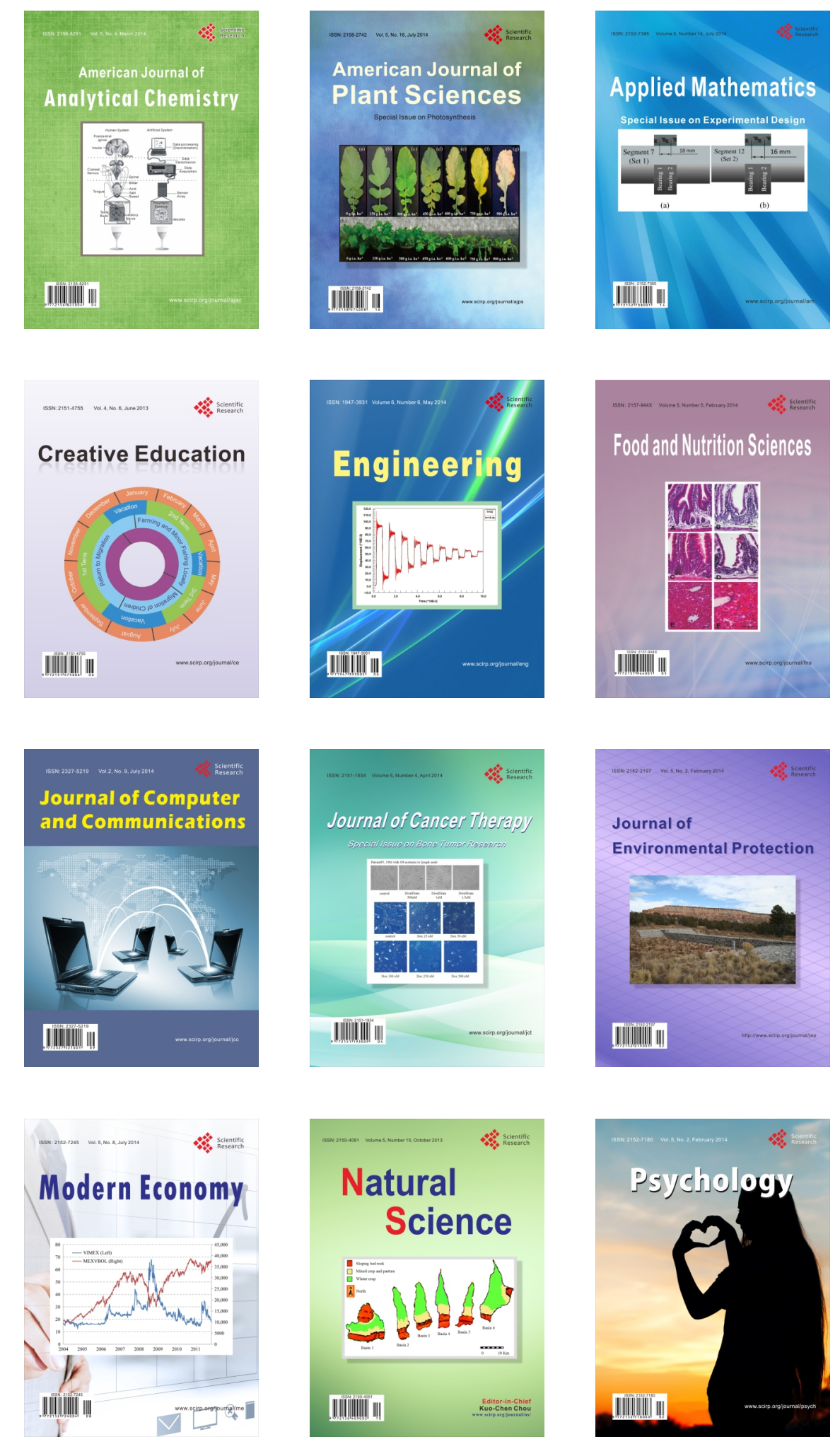